\title{
Decision of Linked with Narcotics Convicted in Act No. 35 Of 2009 in The District of Sumber Court
}

\author{
Heni Agustiningsih ${ }^{1}$ and Sri Endah Wahyuningsih ${ }^{2}$
}

\begin{abstract}
Abstrak. Concomitant with the increasing number of criminal cases concerning criminal law talks even more into the spotlight. One criminal case whose numbers have increased is the narcotic crime. The doers are not limited to age, gender or social strata. Increasing this narcotic crime was accompanied by the use of increasingly sophisticated modus operandi so, make the legislators felt the need to establish a new law governing narcotics. Judge in deciding should consider the value of certainty, justice and the role of the judge is kemafaatan for law enforcement and justice. Article 1 (1) of Act No. 48 Of 2009 regarding Judicial Power.
\end{abstract}

Keywords: Effectiveness; Criminal Law; Narcotics.

\section{Introduction}

The progress achieved in the reform era enough to give hope that better, but on the other hand by the swift currents of globalization is the case today, has caused many problems in almost all aspects of human life. All aspects of social, cultural, religious, political, economic, education, science and technology become prone areas because the changes are fundamental and require a legal umbrella for shelter.

Of the various aspects there are many issues of concern, especially regarding the behavior of some of our young people who are trapped in drug abuse. Narcotics spoken word heard often gives a clue about the impact does not want, this is because the drug once synonymous with evil, forbidden and breaking the rules.

Drug abuse in Indonesia is a very worrying problem for Indonesia's current position not only as a regional transit and marketing of drugs, but has become a local drug manufacturer. This is evidenced by the unfolding of the factories manufacture narcotics in great shape from abroad to Indonesia. Because now where Indonesia is very strategic and not far from the golden triangle (Laos, Thailand, and Myanmar) and the region crescent (Iran, Afghanistan, and Pakistan) which is a regional producer of opium in the world, making Indonesia the traffic dark narcotics.

Drug abuse among the general public intimated to us for care and attention more specifically to cope with, because of the danger posed to threaten the existence of the younger generation that we expect will become the heir and successor of the national struggle in the future.

To set the above problems, the existence of the criminal law is required. Criminal law as one part of the law in general does not show any differences with other laws, namely that all the law contains a number of provisions to ensure that the norms

\footnotetext{
${ }^{1}$ Student of Master of Law, Universitas Islam Sultan Agung Semarang and State Attorney Cirebon Email: agustinheni50@gmail.com

${ }^{2}$ Lecturer of Faculty of Law Unissula
} 
contained in the law obeyed by the people. This indicates that essentially all of the laws aimed to create a harmony, order, rule of law and others in the association of community life.

However, in the case of criminal law reveals a difference of laws in general, which is that in which people recognize the existence of a deliberate intention to provide a legal effect in the form of a bijzondere leed or a suffering of a special nature in the form of a punishment to them who has committed an offense or prohibitions specified therein. ${ }^{3}$

Along with the increasing number of criminal cases concerning criminal law talks even more into the spotlight. One criminal case whose numbers have increased is the narcotic crime. The doers are not limited to age, gender or social strata. Increasing this narcotic crime was accompanied by the use of increasingly sophisticated modus operandi so, make the legislators felt the need to establish a new law governing narcotics.

In 2009 have been established Act No. 35 Of 2009 on Narcotics which is an amendment of the Act No. 22 of 1997 on narcotics because, Act No. 22 Of 1997 on Narcotics is considered incompatible with the development of the situation and the growing conditions to combat and overcome the narcotic crime is increasingly widespread. Since Act No. 35 Of 2009 on Narcotics apply the Act No. 22 Of 1997 on Narcotics revoked and declared invalid. Article 153 of Act No. 35 Of 2009 on Narcotics states:

- Act No. 22 Of 1997 on Narcotics (Official Gazette of the Republic of Indonesia Of 1997 Number 67, Supplement to State Gazette of the Republic of Indonesia Number 3698); and

- The Annex on the type of Schedule I and Group II as contained in the annex to Act No. 5 of 1997 on Psychotropic Substances ((Official Gazette of the Republic of Indonesia Of 1997 Number 10, Supplement to the State Gazette of the Republic of Indonesia Number 3671) which has been moved into Narcotics Group I according to law of this, revoked and declared invalid. ${ }^{4}$

Article 153 of Act No. 35 Of 2009 on Narcotics above reveals not only the Act No. 22 Of 1997 on Narcotics revoked and declared invalid However, Article 153 Paragraph b has stated also the type of psychotropic class I and class II moved into narcotics so that the attachment psychotropic class I class I and class II in Act No. 5 of 1997 on psychotropic revoked and declared invalid.

Narcotic crime included in the special crimes, therefore, Act No. 35 of 2009 on Narcotics is also a special criminal laws apply that in its application based on the principle of lex specialis derogate legi generalist means that special laws override enactment the common law. the legal basis of this principle is Article 103 of the Code of Penal hereinafter we call the Penal Code, Article 103 of the Penal Code states: "The provisions of Chapter I to Chapter VIII of this book also applies to acts by the provisions

\footnotetext{
${ }^{3}$ P.A.F. Lamintang 1997 Dasar-Dasar Hukum Pidana Indonesia Bandung: Citra Aditya Bakti p. 16.

${ }^{4}$ Act No. 35 Of 2009 on Narcotics Chapter XVII Section 153.
} 
of regulations other invitations shall be sentenced, unless the statute otherwise specified ". 5

The plight of a special nature in the form of a penalty was certainly unavoidable in the parts of the law in general, that if people wanted to be the norms contained in it really would be obeyed by the people. In the civil law, for example, people familiar with the confiscation of the property of the institution for someone to recover the losses that have been caused by the actions of others. A foreclosure that has been decided by the judge certainly can lead to a suffering in people whose wealth has been confiscated. But the suffering of a special nature in the nature of criminal law is very different from suffering in civil law.

The existence of the sufferings of a special nature in the form of penalties as has been said above causes of criminal law to get a place of their own among the laws of the other, so that in the opinion of scholars, criminal law it should be seen as an ultimum remedium or as a measures to be used as a final attempt to correct human behavior, and it is natural when one wants the criminal law in its application must be accompanied by restrictions as tight as possible. ${ }^{6}$

By knowing the various kinds of hazards posed on drug abuse, then all forms of abuse of illicit goods was regulated in Act No. 35 of 2009 On Narcotics. The formation of these laws is a picture of this country incessant maintain the criminalization of narcotics users. In addition, the formation of these laws is the embodiment consistency proactive attitude Indonesia supported the international community in the fight against all forms of narcotic crime.

The Proaksi by the issuance of Act No. 7 of 1997 on ratification of the United Nations Convention Against Illicit Traffic in Narcotic Drugs and Psychotropic Substances, 1988 (United Nations Convention on Combating Illicit Traffic in Narcotic Drugs and Psychotropic Substances, 1988) and the Act No. 8 of 1976 on the 1961 Single Convention on Narcotic Drugs and its Protocol of 1972 that Turn. ${ }^{7}$

The purpose of criminal law for human behavior enough memperbaki collided with the condition of Indonesia today. The paradigm has been adopted by Indonesia during this time should be recognized as a major factor of the practice of dehumanization against drug users. Paradigm countries steoritif against infectious drug users and establish a new paradigm in the community so that users narkotikasering times considered trash, criminals, and various stigma that can be said to be discriminatory and leads to dehumanization.

In addressing this, the government in formulating the laws of Narcotics have entered rehabilitation in the legislation. Can be seen in Article 54 of the Narcotics Act which states "Narcotic addicts and victims of abuse of narcotics are required to undergo medical rehabilitation and social rehabilitation. Additionally, in the form of medical rehabilitation that can be acquired in hospitals and rehabilitation institutions specifically appointed by the minister (Article 56), social rehabilitation can be obtained

\footnotetext{
${ }^{5}$ Moeljatno 2008 Kitab Undang-Undang Hukum Pidana. Jakarta: PT. Bumi Aksara

${ }^{6}$ P.A.F. Lamintang Dasar-Dasar Hukum Pidana Indonesia p. 17

${ }^{7}$ Aziz Syamsuddin MAF 2011 Tindak Pidana Khusus Jakarta: Sinar Grafika p. 90
} 
at government agencies and the public (Article 58). In this case that meant government agencies eg Narcotics Penitentiary.

The formulation of its Articles are sufficient only for research, is whether in practice in the field ready to accept the determination, the decision and the judge's order as stipulated in that Article.

In Indonesia today, the imposition of criminal sanctions in the form of imprisonment by judges for criminal narcotics is one of the criminal policy adopted by the Narcotics Act and can not be separated from the norms of criminal law adopted by the criminal law so far, for example in Article 10 of the Criminal Code. Another case in other parts of the world significant developments towards drug users to perform actions aimed at its depenalisasi to replace imprisonment penalty is sometimes applied to other criminal sanctions such as sanctions social work (Community Service Order).

The lack of a Judge's decision that ordered the rehabilitation of addicts Narcotics caused by various factors namely: First, the judge must look case by case basis if it will apply Article 54 of the Narcotics Act. The reason, the construction of penalties for narcotics cases is punishable high. For example, set the Narcotics Act any person who unlawfully or against the law to plant, maintain, possess, store, control, or provide narcotics group I threatened with a maximum imprisonment of 20 years. As for class II and III threatened with a maximum imprisonment of 10 years. Second, in addition to the Narcotics Act, the Supreme Court (MA) issued Circular No. 1 of 2000 on the Criminalization order commensurate with the weight and nature of the crimes. ${ }^{8}$

Although it has been stipulated in the new legislation, but to date there has been no concrete form in the regulation to put narkotikatidak users only criminals but also emphasizes that the user is the victim who must also be restored.

In addition to those described above, the science and practice of law in general often creates problems concerning the existence of the rule of law, and the effectiveness of legal norms with the pulled-center the effectiveness of the law. That is efektvititas law will be highlighted on the objectives to be achieved.

\section{Research Methods}

The method used in this research is the approach of the case. Approach to identify and conceptualize the case was legal sesbagai real social institutions and functional in a real life system. ${ }^{9}$ Sociological juridical approach is emphasizing research aimed at obtaining legal knowledge empirically by road directly involved keobyeknya is to know the legal protection against perpetrators of crimes committed in the District Court of narcotics cases in Sumber.

Qualitative research is a research aimed to describe and analyze the phenomena, events, social activities, attitudes, beliefs, perceptions, thoughts of people individually or in groups. Some descriptions are used to discover and explain the principles that lead to the inference. Qualitative research is inductive. Researcher let problems arise

\footnotetext{
${ }^{8}$ Quoted from http://my--anne1.blogspot.com/2009/01/analisis-yuridis-penerapan-sist accessed on 05.24.2018

${ }^{9}$ Soerjono Soekanto 1987 Pengantar Penelitian Hukum Jakarta: UI Press p. 51
} 
from the data or left open for interpetasi. Data collected by a detailed investigation, includes a detailed description of the context in which those records with the results of in-depth interviews, as well as the results of the analysis of documents and records. ${ }^{10}$ Qualitative research is penelititan which intends to understand the phenomenon of what is experienced by the subject of the study such behavior, perception, motivation, action. Qualitative research has two main objectives, the first of which, describe and reveal (to describe and explore) and both illustrate and explain (to describe and explaim). ${ }^{11}$

\section{Results And Discussion}

\subsection{Efforts Carried out by Judge In Case Breaking Narcotics Decision in Sumber Courts}

Judged criminal by the judge in the case of narcotics. use Act No. 35 of 2009 on Narcotic Drugs as its legal basis. Act No. 35 Of 2009 on Narcotics is a special criminal laws. Sudarto argues, "The law specific crime is any criminal laws other than the Criminal Code, which is the main rule of criminal law". ${ }^{12}$ Special criminal laws applicable based on the principle of lex specialis derogate legi generalist means that special laws override the common law. Applicability of the principle of lex specialis derogate legi generalist is based on Article 103 of the Penal Code which states: "The provisions of Chapter I to Chapter VIII of this book also applies to acts by the provisions of other legislation shall be sentenced, unless by law determined other". ${ }^{13}$ Rules of criminal law is regulated outside the Criminal Code as referred to in Article 103 of the Penal Code when seen from the aspect of deviation deviation was still valid, as well as when in Act No. 35 of 2009 on Narcotics there are irregularities then it also remains valid irregularities. One of the irregularities contained in Act No. 35 Of 2009 on Narcotics is imprisonment in lieu of penalty that can not be paid for in the Criminal Code itself when fines can not be paid then replaced with imprisonment.

The provisions concerning imprisonment as a replacement penalty that can not be paid in Act No. 35 Of 2009 on Narcotics regulated by Article 148 which states, "If the decision of a fine as stipulated in this Law shall be paid by the perpetrators of the crime of Narcotics and Narcotics Precursor criminal offense, the offender was sentenced to imprisonment for a period of 2 (two) years as a substitute for criminal penalties that can not be paid ". ${ }^{14}$ The provisions set out in Article 148 of Act No. 35 of 2009 on Narcotics deviate from the provisions set forth in Article 30 paragraph (2) of the Criminal Code, which states, "If fines are not paid, then replaced with a cage". In

\footnotetext{
${ }^{10}$ Gempur Santoso 2005 Metodologi Penelitian Kuantitatif \& kuanlitatif Jakarta: Prestasi Pustaka Publisher p. 49

11 Ibid

${ }^{12}$ Sudarto Kapita Selekta Hukum Pidana Op. Cit. p. 64.

${ }^{13}$ Moeljatno the Penal Code Chapter IX Section 103.

${ }^{14}$ Act No. 35 Of 2009 on Narcotics Chapter XV Section 148.
} 
further Article 30 paragraph (3) of the Criminal Code states: "The duration of confinement replacement is at least one day and a maximum of six months". ${ }^{15}$

This shows that the Criminal Code clearly defines the minimum limit of imprisonment to be served in lieu of a criminal penalty that can not be paid. In contrast to the Act No. 35 Of 2009 on Narcotics, Article 148 of the law does not clearly identify the minimum threshold of imprisonment to be served in lieu of a criminal penalty that can not be paid. This will make it difficult in practice if the perpetrators reality experiment (poeging), repetition (residive), concurus, or inclusion (deelneming) must therefore be returned to the rule of criminal law holding that the Criminal Code.

The rules in the Criminal Code that can be used as a basis for determining the minimum imprisonment in lieu of fines that can not be paid, as defined in Article 148 of Act No. 35 Of 2009 on Narcotics is Article 30 paragraph (3) for the article 30 paragraph (3) the minimum limit is set on the criminal substitute for criminal penalties that can not be paid.

Pursuant to Article 30 paragraph (3) of the Penal Code it became clear that the minimum limit of imprisonment as a replacement penalty can not be paid, as defined in Article 148 of Act No. 35 of 2009 is one day. The existence of the minimum limit of imprisonment as a replacement penalty that can not be paid that will allow the judge to determine the length of imprisonment which is about to be dropped as a substitutes penalty that can not be paid, although in reality the practice of judges faced with the perpetrator who attempted (poeging) repetition (residive), concurus, or inclusion (deelneming).

\subsection{Implementation Effectiveness Abusers Narcotics Criminal District of Sumber Court}

Abuse of narcotics and dangerous drugs in Indonesia in recent years have become a serious problem and have reached the state focus to become a national problem. Victims of drug abuse has been extended such that it goes beyond the boundaries of social class, age, and gender.

Covered not only in urban areas but extended to rural and transcends national boundaries are consequently very detrimental to individuals, communities, countries, especially the younger generation, it may even pose a danger even greater for the life and values of the national culture that could ultimately weaken national defense.

According Parasian Simanungkalit that drug misuse is an extraordinary crime and transnational crime because of the effects of drug misuse not only destroy themselves drug users but also can damage the structure of the life of society, nation and state. The same perspective Lickona said that one characteristic of the disintegration of a state that is the self-destructive behavior such as drug misuse is increasing in the State. ${ }^{16}$

One of the Indonesian government's efforts is confirmed and made of Act No. 5 of 1997 on Psychotropic Substances and the Act 35 of 2009 on Narcotics replace Act

\footnotetext{
${ }^{15}$ Moeljatno the Penal Code Chapter I Article 30 paragraph (2) (3).

${ }^{16}$ Wahyuni Ismail 2014 Remaja dan Penyalahgunaan Narkoba Makassar: Alauddin University Press p. 7.
} 
No.22 of 1997 on Narcotics. Both this Act firmly and clearly provide severe penalties, not only to producers, drug dealers, drug trafficking but also on peyalahguna drugs. ${ }^{17}$ Talking about the effectiveness of a criminal prosecution is certainly not limited to the heavy sentence handed down by the judges or the length of sentencing a convict, but also rely heavily on the facilities and their supporting facilities is in a penitentiary. It can be seen that the existence and the essence of the purpose of a correctional institution is almost certain narcotics differ from prisons in general. In addition to restoring the balance of the attitude of the perpetrators in order to deter and not to repeat the crime again, penal institutions narcotics have an important task to deal with and trying to eliminate drug addiction properties of citizens auxiliaries.

\section{Closing}

\subsection{Conclusion}

Basiclegal considerations of the judge in determining the length of imprisonment as a replacement penalty on narcotics pidna decision. is the weight of the defendant, the weight of guilt of the accused, their theory straftoemeting in sentencing, their ease things and things that are burdensome, as well as the purpose of punishment that are implicit. Sebuak case of narcotics are many factors mostly economic conditions cause he does not carry criminal penalties and prefer to undergo imprisonment which is a criminal alternatives.

\subsection{Suggestion}

- The people should participate actively and fully support the implementation of prevention efforts undertaken by the Drug Res Sat and Police Cirebon, West Java.

- Supporting performance of the National Narcotics Agency of West Java Province by reporting to the authorities, if aware of the occurrence of drug abuse in their environtment.

- Police officers should provide protection to the people who play an active role in the prevention of drug abuse in their environment and to reward to the people who participate in the fight against drug abuse.

\section{Bibliography}

[1] P.A.F. Lamintang 1997 Dasar-Dasar Hukum Pidana Indonesia Bandung: Citra Aditya Bakti

[2] Act No. 35 Of 2009 on Narcotics

[3] Moeljatno 2008 Kitab Undang-Undang Hukum Pidana. Jakarta: PT. Bumi Aksara

[4] P.A.F. Lamintang Dasar-Dasar Hukum Pidana Indonesia.

[5] Aziz Syamsuddin MAF 2011 Tindak Pidana Khusus Jakarta: Sinar Grafika .

[6] Quoted from http://my--anne1.blogspot.com/2009/01/analisis-yuridis-penerapansist accessed on 05.24.2018

[7] Soerjono Soekanto 1987 Pengantar Penelitian Hukum Jakarta: UI Press.

${ }^{17}$ Ibid. 
[8] Gempur Santoso 2005 Metodologi Penelitian Kuantitatif \& kuanlitatif Jakarta: Prestasi Pustaka Publisher.

[9] Moeljatno the Penal Code Chapter IX Section 103.

[10] Act No. 35 Of 2009 on Narcotics Chapter XV Section 148.

[11] Moeljatno the Penal Code Chapter I Article 30 paragraph (2) (3).

[12] Wahyuni Ismail 2014 Remaja dan Penyalahgunaan Narkoba Makassar: Alauddin University Press. 